\title{
ETNOPOlÍTICA ATACAMEÑA: EJes DE LA DIVERSIDAD
}

\author{
Héctor Morales Morgado ${ }^{1}$
}

\begin{abstract}
Resumen
Este trabajo describe nuevas formas de subjetividad política en la era del multiculturalismo. En las últimas tres décadas en Chile y Latinoamérica las etnias se han incorporado a un nuevo escenario político, creado por su reconocimiento jurídico. Reconocer la diversidad étnica ha sido un logro continental, aunque no pasó mucho tiempo para que la conquista democrática se enfrentará a la etnopolítica de la propia diversidad. Una cosa es la diversidad como sistema plural de formas culturales y otra muy diferente es el complicado escenario de las interacciones y limitaciones con que se realiza o no la diversidad en la política. Por ello, aquí se adentra en los ejes de la diversidad cultural atacameña; cómo se construye la etnicidad, sus actores intervinientes y se ahonda en la etnificación como un proceso diferencial, administrativo e inclusivo de población con cualidades culturales heterogéneas. Se muestra un campo o estructura social específica que da cuenta de una etnogénesis y etnopolítica atacameña en el norte de Chile.
\end{abstract}

Palabras Claves: Etnicidad, andina, indígena, etnogénesis.

\begin{abstract}
This paper proposes a description of the new forms of political subjectivity in the Age of Multiculturalism. During the last three decades, in Latin America and Chile ethnic groups have accessed to a new political scenario produced by their legal recognition. The recognition of the ethnic diversity has been a continental achievement; however this democratic conquest had to face very early the ethnopolitical conflicts of diversity itself. One thing is diversity as a pluralistic system of cultural forms, quite another is the complex scenario of interactions and constraints, which makes (or makes not) possible diversity in politics. Therefore, this study explores the main issues on cultural diversity in Atacama, how ethnicity is constructed and who are their intervening actors. It also delves into the analysis of ethnification as an administrative process of differentiation and inclusion of people with heterogeneous cultural qualities. Thus we attempt to show a field or a specific social structure that displays an ethnogenesis process and Atacamenian form of ethnopolitics in northern Chile.
\end{abstract}

Keywords: Ethnicity, andina, indian, ethnogenesis.

Recibido: Enero 2015. Aceptado: Junio 2015

\section{* Introducción}

Este trabajo permite visibilizar la emergencia de sujetos, escenarios y relaciones sociales que configuran procesos etnopolíticos de diferenciación, muestra las diversas perspectivas sobre la etnicidad y cómo estas dan fisonomía al "hecho social" de la diferencia cultural.

En el paradigma de la etnicidad como cultura, prima la idea de etnicidad en un área cultural primordial, y también se presenta la perspectiva constructivista que acentúa el carácter elaborado de las identidades de los grupos étnicos y cómo en estudios más recientes, el concepto ha tomado un giro diferente alejándose de las teorías esencialistas para proponer una versión instrumental de lo étnico, incluso como mercancía.

Por otro lado, la etnicidad puede ser entendida como una relación social que ocurre en un contexto particular, transitorio y temporal, y también se erige socialmente en espacios de frontera cultural. Así, la etnificación en cuanto proceso diferencial, administrativo e inclusivo, sugiere la idea de que hay agentes que etnifican cualidades socioculturales. Estos administradores de la diferencia en Atacama serían; líderes indígenas, arqueólogos, etnohistoriadores y antropólogos.

Se mostrará un campo étnico que nos permite visibilizar la construcción y definición de un sujeto para la política étnica y un sujeto étnico para la política. Es la aparición de un espacio social para resolver los asuntos de la diversidad cultural, una estructura donde se organizan las luchas, conflictos, resistencias y asimilaciones en procesos dinámicos de etnogénesis, siendo este el surgimiento de una nueva entidad sociocultural, como resultado de

1 Departamento de Antropología, Facultad de Ciencias Sociales, Universidad de Chile. Laboratorio de Etnografía. Ignacio Carrera Pinto 1045 , Ñuñoa, Santiago, CHILE. Email: hmorales@uchile.cl . 
procesos de ajuste a los parámetros de integración nacional o mercantil. Debido a ello la continuidad temporal del grupo se hace difusa. Por esta razón, se indagan a los actores/agentes y contextos que permiten reconstruir la génesis atacameña y cómo adquiere su condición étnica en el imaginario nacional.

La metodología utilizada es eminentemente cualitativa y apunta a identificar actores sociales y procesos de etnificación ocurridos en la zona del Salar de Desierto de Atacama en norte andino de Chile. Este artículo se ha realizado en el marco del programa Laboratoire International Associé (LIA), Archéologie, histoire et anthropologie des systèmes miniers dans le désert d'Atacama" del Centre National de la Recherche Scientifique, CNRS. Esta investigación se inició con un análisis bibliográfico que permitió la revisión de información disponible sobre las perspectivas y construcción social de la etnicidad, lo que se complementó con datos etnográficos de líderes y comuneros que permitieron generar tipologías y escenarios relevantes para la política del reconocimiento y las relaciones de poder al interior de los grupos sociales en Atacama.

\section{* Perspectivas sobre etnicidad}

Etimológicamente el término "etnia" proveniente del adjetivo griego ethnikos, que significa "gentil". El adjetivo, a su vez, deriva del sustantivo ethnos que significa "gente o nación extranjera". Sin embargo, a principios del siglo XVIII, este sustantivo dejó de relacionarse con el sentido pagano que inicialmente se le asignó, ya hacia mediados del siglo XX. El uso moderno indica que el vocablo "etnicidad" es una palabra que alude a formas específicas de diferenciación cultural. Estas han sido abordadas con distintos matices desde las tradiciones sociológicas, antropológicas y/o políticas (Gellner 1988). En su traducción al latín, el sustantivo ethnos resulta en "natio", vocablo que también designa a los pueblos bárbaros y lejanos; por oposición a los romanos que se auto-denominaban populus, y no como natio. Por otro lado, en inglés sólo posee el adjetivo "étnico" y no el sustantivo correspondiente, conservando este sentido del Nuevo Testamento: ethnics significaba "pagano" o "gentil" (Giménez 2006).

Esta trayectoria en el uso del término, ampliamente difundida hoy entre académicos y legos, fue sistematizada por la sociología norteamericana a través del concepto de "etnicidad". Este vocablo fue usado en 1945 por Warner Lloyd en The Social Systems of American Ethnic Groups y luego por David Riesman, quien en 1953, siguiendo el legado ya clásico de Robert Park en los inicios del siglo XX, en la llamada Escuela de Chicago de la sociología interaccionista, se interesa por las limitaciones étnico-culturales en barrios de inmigrantes de las grandes ciudades de Estados Unidos; espacios donde se erigían verdaderos ghettos de exclusión social y económica, pero estos ya no eran los ghettos amurallados de la Edad Media europea. Estas nuevas murallas corresponden al estigma racial, cultural y social, la reproducción de la pobreza endémica y las múltiples asimetrías del poder social implicadas en las sociedades modernas. La visión interaccionista fue introducida en la antropología por Frederik Barth, autor que tuvo influencia en Latinoamérica en la década del setenta.

En Europa, en cambio, "etnia" ha sido históricamente un sinónimo de nacionalidad, es ejemplar lo definido por la tradición alemana como Volksgeist o pertenencia territorial, sea por descendencia o por vínculo de sangre ${ }^{2}$. Al mismo tiempo y debido a factores históricos ha operado a modo de sinónimo del concepto "raza", sobre todo a partir de la condena y cuestionamiento del nazismo después de la Segunda Guerra Mundial. No obstante, esta idea de reemplazo del concepto de raza por el de etnicidad, ha provocado que el término se encuentre fuertemente racionalizado a propósito del racismo y manifestaciones nacionalistas etnocéntricas.

Mientras en Europa lo "étnico" puede aludir a las antiguas nacionalidades que dieron origen a los modernos Estados-nacionales, en América Latina alude a pueblos

2 Volksgeist germano es un concepto propio del nacionalismo romántico que atribuye a cada nación unos rasgos comunes e inmutables a lo largo de la historia. El nacionalismo cultural o étnico siempre incluye algunos elementos descendientes de las generaciones previas e ideas de una conexión cultural entre los miembros de la nación, sus antepasados y frecuentemente con un lenguaje común así nacionalidad es hereditaria. El Estado deriva la legitimidad política de su estatus como hogar del grupo étnico, protector del grupo nacional y facilita la vida social y cultural, "un Volk debe ser fiel a sí mismo, es decir, a su propia cultura”, para el nacionalismo étnico moderno está fuertemente influido por J. G. von Herder (Taylor 2003: 51). 
originarios, grupos descendientes directos de las primeras poblaciones que habitaron el continente. Pese a que la categoría de "indio" e "indígena" tiene sentidos múltiples, el concepto refiere a una condición histórica que emerge de la conquista hispánica y de su posterior proyección poscolonial en las repúblicas criollas (DíazPolanco 2006; Degregori 2004; Bartolomé 2004; Boccara 2002). Lo étnico se vincula, pues, a un esquema de dominación que se extiende desde el estigma de la identidad cultural degradada al sometimiento político y la exclusión socioeconómica (Stavenhagen 1992, 2000, 2001; Foerster 1999; Bello 2004; Hopenhayn 2005; Vergara et. al. 2013).

Esto ha llevado a que el término "etnia" sea usado, por lo general, como un eufemismo para "raza" o un sinónimo para grupo minoritario, e incluso para designar a grupos nacionales. Este sesgo etnocéntrico del término "etnia", que tiende a infiltrarse furtivamente incluso en el lenguaje académico, implica que todos los grupos pueden ser étnicos dentro de una comunidad, menos el grupo que tipifica, ya que éste es el que clasifica a todos los demás. Dependiendo de los enfoques teóricos usados, las operaciones conceptuales nos llevarán a distintas explicaciones sobre el fenómeno étnico; así la etnicidad será sinónimo de cultura o frontera cultural.

\section{Etnicidad como cultura}

En este paradigma, prima la idea de etnicidad como equivalente a la identidad cultural, en una operación epistemológica que concibe la cultura como cerrada, homogénea y ubicada en un área territorial. Este afán culturalista, si bien eficiente en su propósito de dar visibilidad y legitimidad a grupos culturales subalternos, ha tenido un costo significativo. Justamente el proyecto político de los estados nacionales ha sido y es la construcción de sujetos sociales ajustados a las hormas de las políticas públicas de integración social. Por otro lado, la idea de una "identidad étnica" supone resolver el fuerte contrasentido entre el concepto etnia en su sentido de "diferencia cultural" o extranjería, y la idea de identidad del latín "identitas", derivado de "ídem" que significa "lo mismo". Esa operación simultánea de semejanza y diferencia concluye como resultado con la idea de una identidad colectiva extranjera, más o menos homogénea, traducible y visible.
A inicios del siglo XX, los rasgos culturales materiales u "objetivos" de un empirismo ingenuo, demostró ser ineficiente - puesto que pretendía definir "lo distintivo" basándose en elementos materiales y simbólicos provisorios que cambiaban con el tiempo. Fue Max Weber (1922), quien explicó a los grupos étnicos como colectivos que poseen una creencia subjetiva en un origen común, fundada en la apariencia o en alguna base que sustentaría su proceso de comunalización. Esto es independiente de que exista o no una real comunidad de sangre. Para este autor, el grupo étnico no constituye una comunidad en sí misma, sino un momento que facilite el proceso de comunalización, definiendo a los grupos étnicos como:

“aquellos grupos humanos que, fundándose en la semejanza del hábito exterior y de las costumbres, o de ambos a la vez, o en recuerdos de colonización y migración que abrigan una creencia subjetiva en una procedencia común" (Weber 1944: 318).

Así, la creencia en una comunidad de sangre con un sentimiento de honor específico - el étnico - gatilla en Max Weber las alusiones claras al carácter artificial y construido de las tribus y de los grupos étnicos. Dentro de esa perspectiva no están ausentes aquellos investigadores que han entendido la etnicidad como una extensión o metáfora de las relaciones de parentesco, en la medida en que un grupo étnico tiende a asumir una ascendencia común o cree compartir lazos de sangre (Weber 1944; Murdock 1957; Narroll 1964). En estos autores se aprecia la emergencia sociológica del modelo social constructivista de la etnicidad. Los grupos étnicos serían "lo que la gente cree o piensa ser"; mientras que la identificación étnica se construiría tanto fuera como dentro de la interacción entre grupos. Aún hoy, la idea de los grupos étnicos como colectivos naturales, reales, inmutables, estables y casi estáticos se mantiene vigente. En tanto, objeto de estudio, cada grupo produce un continuum esencial de mitos y rasgos o conocimientos, donde el elemento central es la preservación y la supervivencia del grupo que se siente amenazado, pues habitualmente los conflictos parecen provenir del mundo exterior al grupo étnico que se analiza (Sollors 1991).

Perspectiva primordialista. Se suele identificar a E. Shils (1957) como el primero en sugerir la noción de primor- 
dialismo para fundamentar su propuesta acerca de la importancia de los grupos primarios en la configuración de las sociedades complejas. Grupos que hacen a los seres humanos orientar su conducta a partir de los fuertes vínculos de solidaridad que generan. Sin embargo, también es frecuente atribuir a C. Geertz $(1963,1993)$ la sistematización de esta perspectiva en su análisis de la constitución de los nuevos Estados nacionales, donde comúnmente los grupos étnicos se confrontan con las instituciones estatales, es decir, el nuevo orden civil se convierte en una amenaza para las identidades étnicas tradicionales, con solidaridades ligadas a la sangre, lengua y creencias. Elementos que son calificados como "un producto de la activación de sentimientos primordiales vagamente definidos" (Geertz 1963: 105). Según el autor, los vínculos primordiales revisten ciertas características típicas: se presentan como "datos" a priori rebeldes a todo análisis; son percibidos como algo inefable, poderoso, coercitivo y sobre todo, son capaces de generar fuertes emociones y afectos. La propuesta de Geertz 1997 [1973] plantea que una de las dificultades de los nuevos Estados surgidos de la descolonización, es la persistencia de vínculos primordiales que dificultan la adhesión a un Estado percibido burocrático, civil, frío y abstracto. Se trata, por lo tanto, de un clásico problema de lealtades que se expresa en diversos tipos de solidaridades grupales. Posteriormente, Walter Connor sostendrá que sin el concepto de "vínculos primordiales" no entenderíamos, por ejemplo, la fuerza irresistible de los etno-nacionalismos tan frecuentes en los estados multinacionales. En efecto, "la nación se construye siempre a partir de una comunidad étnica" (Connor 1994: 206).

No obstante lo expuesto, creemos aquí que el debate entre los primordialistas y sus críticos se sustenta en un falso debate. En efecto, no se puede negar la especificidad de los vínculos étnicos en comparación con otros vínculos como los civiles, políticos y de clase, entre otros. La etnia es un grupo de parentesco ampliado. No importa que sea real o ficticio, lo que le confiere la fuerza coercitiva es un deber moral para con "los suyos" y una fuerza emocional que despierta el simbolismo de los vínculos de sangre y de familia (Isaacs 1975). Pareciera ser que el primordialismo, tan criticado, es una consecuencia de la definición política de la etnicidad en términos de "consanguinidad". El mayor reproche al primordialismo es la idea de sociedades cerradas y estables.
Perspectiva constructivista. Por otra parte, las teorías constructivistas acentúan el carácter elaborado de las identidades de los grupos étnicos, en cuya constitución se evidencian componentes históricos, lingüísticos, culturales e imaginarios. La idea de construcción social en la línea de análisis de P. Berger y T. Luckmann (1973), constituye un enfoque particularmente útil para el estudio de procesos de etnogénesis y de etnificación tanto histórico como contemporáneo (Roosens 1989). Esta perspectiva se nutre de formulaciones teóricas referidas a la formación de naciones a partir de la "invención de la tradición" de E. Hobsbawm (2002) o de las "comunidades imaginadas" de B. Anderson (1993). Pero los constructivistas a ultranza tienden a ignorar el hecho de que etnias y naciones no son unidades equivalentes; aunque sí constituyen comunidades culturales que pueden ser similares al poseer identidades exclusivas. La mayor diferencia radica en que la nación es una colectividad de identificación construida por un Estado y sus aparatos hegemónicos, mientras que, las etnias sin Estado, por lo general, carecen de canales de comunicación generalizado que favorezcan el compartir tradiciones inventadas o imaginar una existencia comunitaria producto de la convivencia cotidiana o de una ancestralidad compartida. Es así como en el marco de los procesos de modernización, lo étnico puede estar en un sentido vinculado a formas de integración o exclusión social, pero también puede referirse a los procesos de construcción social de una alteridad o a un esquema bio-político de agrupamiento y organización social en torno a la idea (real o imaginada) de grupos consanguíneos extendidos. A lo anterior se suma que lo étnico también se asocia con membrecía; vale decir, con la pertenencia a un grupo específico sea por proximidad territorial, lazos históricos o vínculos culturales y/o religiosos (Anderson 1993). Los seguidores del constructivismo intentan destacar el carácter procesual del desarrollo de las ideologías étnicas que tienden a asumir referentes emblemáticos, tanto materiales como simbólicos, para legitimarse ante los grupos con los cuales se confrontan.

Perspectiva instrumental. Otra perspectiva teórica ligada al constructivismo es la instrumentalista, tendencia en cierto modo predominante a partir de las propuestas de A. Cohen (1974), y de N. Glazer y D. Moyniham (1975). Para los instrumentalistas, la identidad étnica es básicamente un recurso para la movilización política, la cual 
es manipulada para obtener determinados fines. Glazer y Moyniham fueron de los primeros en señalar que un grupo étnico funciona precisamente como un grupo de interés. Cohen, autor clave del instrumentalismo, define taxativamente al:

"grupo étnico como una colectividad con intereses en común, que manipula sus formas culturales (parentesco, mitos, ritos, etc.) para competir o defender dichos intereses" (Cohen 1974: 308).

Aquí, la etnicidad aparece como una contingencia transitoria y no en tanto un dato en sí mismo. Esta explicación resultó muy útil para los comportamientos étnicos en ámbitos migratorios urbanos y luego fue desafortunadamente generalizada. El uso estratégico de la etnicidad juega un papel fundamental en el mantenimiento de las identidades de acuerdo con las circunstancias. Dicho uso se expresa en el esfuerzo consciente de líderes, individuos y comunidades en pro de la movilización de signos étnicos para acceder a recursos y derechos económicos, sociales y culturales.

\section{Etnicidad como relación}

El paradigma relacional propone una forma de organización más cambiante, transitoria y contextual, orientada a regular la interacción social a través de la organización de la diferencia y la auto adscripción. Por lo que las identificaciones étnicas resultantes no se vinculan necesariamente a un patrimonio cultural exclusivo. La categoría frontera o límite aparece así como un rasgo fundamental de lo étnico, ya que la misma existencia del grupo depende de la pertinencia de sus límites. El enfoque generativo o interaccionista, acuñado por Fredrik Barth (1976) y ampliamente difundido por su carácter dinámico e interactivo, disocia al grupo étnico de la tradicional relación con una cultura específica. Las identidades se erigen para contrastarse, de manera tal que: a) los grupos étnicos deben considerarse una forma de organización la organización social de las diferencias culturales. Esto quiere decir que hacia adentro y hacia fuera del grupo, las relaciones sociales se organizan a partir de diferencias culturales, b) tales diferencias culturales no se suponen objetivas; están subjetivamente definidas y seleccionadas como significativas por los actores sociales. De esta manera se clasifican a sí mismas y a la vez son clasificadas por otros con fines de interacción, he aquí la importancia central de la auto adscripción y de la hetero-adscripción categorial en la teoría de Barth, c) la identidad étnica se constituye y transforma en la interacción de los grupos sociales mediante procesos de inclusión-exclusión, los cuales establecen fronteras entre dichos grupos, definiendo quiénes pertenecen o no a los mismos, y d) la identidad de los grupos étnicos se define por la continuidad de sus fronteras, a través de procesos de interacción inter-étnica, y no por las diferencias culturales que, en un momento determinado, marcan o definen tales fronteras. $\mathrm{O}$, dicho en otros términos, pueden variar los "emblemas de contraste de un grupo" sin que se altere su identidad, en efecto;

"gran parte del contenido cultural que en un momento determinado es asociado con una comunidad étnica no está restringido por estos límites; puede variar, puede ser aprendido y modificarse sin guardar ninguna relación crítica con la conservación de los límites del grupo étnico" (Barth 1976: 49).

Si bien las categorías étnicas presuponen diferencias y marcadores culturales, no se puede suponer una simple relación de equivalencia entre las unidades étnicas basada exclusivamente en la observación de similitudes o diferencias culturales. El aporte del enfoque étnico a partir de Barth supone que, a pesar de compartir marcadores, los grupos establecen relaciones de distinta jerarquía o importancia con cada uno de ellos. Por lo tanto, en vez de hacer desaparecer las diferencias culturales que existen entre ellos, los mismos marcadores pueden hacer que se refuercen (Barth 1995). Ciertos elementos culturales ejercen como marcadores de diferencia. Su importancia aparente va cambiando conforme se modifican las relaciones del grupo cultural al que pertenecen y el contexto en que dichas relaciones se dan. El grupo — tal y como se reconoce- existe por su contraste con el otro; contraste que se expresa por medio de los marcadores culturales: organización, religión, lengua y territorio entre otros.

La pertinencia de este enfoque, apunta a la irrelevancia en que quedan los aspectos culturales, ya que si nos atenemos estrictamente a lo organizacional, cualquier grupo corporativo podría ser considerado en términos étnicos. Incluso E. Roosens (1989) apunta a que la noción de frontera, punto focal en el análisis de Barth, supone que este tipo de límites a la interacción puede generar identi- 
dades, pero no necesariamente identidades étnicas. Las críticas a este enfoque se asocian al riesgo implícito de no poder distinguir las identidades étnicas de otro tipo de identidades sociales como las locales o regionales.

Es por ello que H. Vermeulen y C. Govers (1994: 3) sugieren que la identidad étnica remite precisamente a "la conciencia de la diferencia", siendo a la vez una expresión y una parte de la cultura. Entonces resulta necesario distinguir entre conciencia e identidad étnica. Se dijo antes que la identidad remite a la idea de unidad. En cambio la conciencia étnica remite al reconocimiento de la diferencia. Algo así como;

"las manifestaciones ideológicas del conjunto de las representaciones colectivas derivadas del sistema de relaciones interiores de un grupo étnico, las que se encuentran mediadas por la cultura compartida" (Bartolomé 2004: 71).

Se trata de otorgarle un papel específico, en las configuraciones identitarias, a los referentes culturales derivados de la socialización y a las relaciones contrastivas. Las que en conjunto influyen en el tipo de definición del "nosotros étnico"s.

"el conjunto de repertorios culturales interiorizados (representaciones, valores, símbolos) a través de los cuales los actores sociales (individuos o colectivos) demarcan simbólicamente sus fronteras y se distinguen de los demás actores en una situación determinada, todo ello en contextos históricamente específicos y socialmente estructurados" (Giménez 2000: 28).

Por lo general, se trata de grupos sociales cuya lógica cultural se aprecia a veces difusa e incomprensible y en cuyos sistemas organizativos juega un papel relevante el parentesco u otras formas asociativas y solidaridades internas. Son sociedades que, en general, han sido definidas desde afuera de ellas mismas e históricamente utilizada por sociedad dominante para designar a grupos culturalmente diferentes. Por ello, la etnia y la etnicidad son etiquetas científicas clasificatorias, es decir, un rótulo o término exógeno a las culturas identificadas.

Se consigna por último el "etnicismo" como negativo en cuanto es la exacerbación del otro como algo exótico y fetichizado, en un proceso vinculado a la visibilidad mercantil, es decir constituir la alteridad en un producto, que no logra concretarse, pues es un estereotipo, un imaginario (Comaroff y Comaroff 2011). El mercado da visibilidad a un fenómeno virtual asociado a dicotomías nativo versus lo limpio, sustentable versus modernidad industrial tóxica, etc. Consecuentemente, en ciertos casos incluso aparecen procesos de teatralización o creación cultural para contestar al deseo de exotismo del consumidor que ciertos autores han llamado la "alienación de la cultura". En suma, la etnicidad, como lo concluyen los Comaroff, resulta ser un fenómeno muy complejo, que tiene velocidades y grados diversos, que es diferente en cada situación y que está siempre cambiando.

\section{Etnicidad atacameña}

En los últimos treinta años, tanto líderes indígenas como investigadores y académicos han entrado en un nuevo escenario político, producido por su reconocimiento jurídico multicultural ${ }^{5}$. Con este nuevo estatus jurídico las prácticas culturales de los atacameños adquirieron una legitimidad mayor, pero una cosa es la política y otra, muy distinta, el complicado escenario del reconocimiento de

3 Esta idea de estructuras específicas que acogen un conjunto de relaciones interculturales nos puede remitir a la idea de "Habitus". Es decir, estructuras predispuestas a actuar como estructurantes, que no sólo sirven para distinguir un nosotros de los otros; sino que también sirven para organizar la vida de nosotros, ya que, es el papel central de todo sistema cultural (Bourdieu 1990).

4 Según los Comaroff (2011, 2013), esta nueva etnicidad posee siete dimensiones: (i) la biologización de la pertenencia, (ii) los procesos de etnogénesis a partir del mercado (objetivación y visibilización de las prácticas culturales), (iii) la aparición del capital de riesgo y del capital externo, (iv) el hecho que las etnoempresas no siempre están sostenidas por el contenido de la diferencia cultural, (v) la afirmación de la soberanía propia siempre en detrimento de la del Estado (luchas legales), (vi) el reclamo de un territorio (incluso virtual), y (vii) una dialéctica entre la mercantilización de la cultura y la incorporación de la identidad.

5 Lo multicultural es el hecho social de la diferencia, el multiculturalismo es una intención política de la integración de la diferencia y la multiculturalidad es una identidad que conduce políticamente las relaciones sociales de la diversidad (Zambrano 2002). 
la diferencia (Zizek 1998; Kimlicka 1996). El multiculturalismo en Chile ${ }^{6}$ puede identificarse en la resolución de la "cuestión indígena" que se abrió camino a raíz de cambios de gran envergadura, como la constatación jurídica de culturas tradicionales, la emergencia de movimientos sociales que promueven estilos de vida alternativos, las reivindicaciones etno-nacionales o la intensificación de los fenómenos migratorios. Estos fenómenos sociales emergentes pusieron en aprieto la homogeneidad, la universalidad de las estructuras y las representaciones de la sociedad. Como consecuencia, se produjo un tránsito de la unicidad a la diferencia que provocó el surgimiento de un conjunto de nuevas problemáticas políticas.

Para la comprensión de lo étnico atacameño, como equivalente a la identidad cultural atacameña, se instala una operación epistemológica que concibe la cultura en un área, es un lugar donde todos los habitantes pertenecientes al grupo tienen cualidades más o menos similares en lo cultural. Aún hoy, la idea de "lo atacameño" como colectivo natural, real, inmutable, estable y museístico se mantiene vigente. Algunos líderes e instituciones académicas producen y reproducen un continuum primordial de mitos y conocimientos, donde los elementos centrales son la preservación y supervivencia atacameña. Otra perspectiva es la constructivista en Atacama que logra dar cuenta de los procesos de construcción social de alteridad - por consanguinidad, proximidad territorial, lazos históricos o vínculos culturales y/o religiosospermite configurar la unidad cultural. Así, por ejemplo, el ayllu o la comunidad indígena, es un esquema biopolítico de agrupamiento, una organización social (real o imaginada) de grupos consanguíneos extendidos con una membrecía particular. Esta estrategia constructiva nos da la unidad atacameña, pese a las diferencias entre los distintos grupos que habitan Atacama.

En cambio, bajo la perspectiva interaccionista, lo Atacameño se muestra hacia afuera como la adscripción que da unidad a todos los pobladores de Atacama, pero hacia adentro se reconoce que sólo los pobladores de San Pedro de Atacama serían los atacameños y se agregan dos grupos importantes, los collas y quechuas, ambas denominaciones rotuladas por los atacameños de San Pedro de Atacama. Estos últimos (quechuas/collas) negarán estos apelativos y se auto adscriben a los gentilicios derivados del nombre de sus pueblos de residencia o locali- dades. Así "lo atacameño" es una forma de organización, la organización social de las diferencias con su entorno nacional. Tales diferencias no son sólo rótulos externos respecto al color de piel, vestimenta o formas de hablar, sino que están subjetivamente definidas y seleccionadas como significativas por los actores sociales indígenas, quienes se clasifican a sí mismos y a la vez, son clasificados por otros con fines de interacción. La etnicidad atacameña se transforma en la interacción con los grupos sociales, mediante procesos de inclusión-exclusión, donde se establecen los parámetros de integración a la etnia (Morales 2013).

El etnicismo atacameño, por otro lado, nos permite entender y aglutinar fenómenos asociados a la defensa de los derechos intelectuales y territoriales por parte de las organizaciones y movimientos indígenas atacameños que han revitalizado imaginarios sobre el antiguo y preexistente orden social atacameño y su consiguiente control/ dominio sobre sus territorios. Así, la judicialización de la vida social se vincula a la defensa legal, litigante ante los tribunales de justicia, la formalización de los derechos de propiedad sobre lugares, prácticas y objetos culturales (textiles, arte rupestre, bailes, imágenes iconográficas, etc.). Esta hegemonía de la propiedad intelectual en una economía de la diferencia cultural, reafirma y fortalece la naturalización de la identidad como una forma más de propiedad individual o colectiva. Ello se ha expresado en

$6 \mathrm{Al}$ asumir el nuevo Gobierno de la Concertación en 1990, se crea la Comisión Especial de Pueblos Indígenas (CEPI). Su objeto era realizar programas y proyectos que aporten al desarrollo integral de los pueblos indígenas como parte integrante de la sociedad chilena, y muy especialmente, a fin de estudiar y estructurar las propuestas formuladas por las organizaciones indígenas y plasmarlas en una propuesta legislativa. La aspiración de las organizaciones indígenas fue su reconocimiento como tales, y la exigencia de que este reconocimiento valorará su cultura y diversidad como integrantes de la sociedad chilena, pero respetando sus particularidades. La CEPI inició un proceso de discusión de los contenidos de la nueva legislación en forma participativa que culmina en un Congreso Nacional de Pueblos Indígenas en enero de 1991. La primera información que recibieron los pobladores de Atacama respecto de la Ley Indígena número 19.253, aprobada en Septiembre de 1993, se refiere a iniciar un proceso de inscripción de los, hasta ese momentos, "poblado" o "localidades" en "Comunidades Indígenas Atacameñas". 
diversos conflictos etno-ambientales, oposiciones legales y recursos de protección en Pampa Colorada, Géisers del Tatio, exploraciones mineras, instalaciones de hoteles y obras viales, entre otros.

Recapitulando, cada una de estas perspectivas mencionadas nos brinda una posible explicación sobre el fenómeno étnico atacameño. Detrás de cada opción metodológica y teórica hay axiomas que dan sustento al fenómeno mismo de la etnicidad. Nuestra elección es la unidad dada por las relaciones y fronteras interculturales, las que tienen mayor capacidad explicativa de la dinámica étnica atacameña.

\section{* La etnificación atacameña: Proceso DIFERENCIAL, ADMINISTRATIVO E INCLUSIVO}

Con los conceptos aquí expuestos, examinaremos la pertinencia desde la perspectiva relacional, para el caso de la emergencia de la etnia atacameña; en cuanto, contexto y vínculos sociales que generan las organizaciones sociales a partir de las diferencias históricas proyectadas a través de dinámicas socio y etno políticas entre los distintos grupos sociales existentes en Atacama. El sujeto social atacameño bajo esta perspectiva es cambiante, transitorio, contextual y temporal, lejos de un sujeto estable, fijo y de una larga trayectoria naturalizada y primordial. Proponemos una definición operativa a la etnificación como la acción de dotar de sentido racional a la diferencia cultural difusa, para luego normalizar y transformar lo incognoscible a entendible. Es el acto de historizar, sociologizar y antropologizar la diferencia, se trata de generar un verosímil, un estrato de información y de sentido sobre lo atacameño. Se sugiere que hay agentes que integran la diferencia a través de la etnificación, es decir, dan una fisonomía específica a los cuerpos sociales como conciencia, identificación, percepción o prácticas sociales con sentido cultural. Esto conforma una comunidad imaginaria unida ya sea por redes de parentesco, solidaridades locales, por memorias u olvidos socialmente compartidos (Anderson 1993; Escolar 2007).

\section{Administradores de la diferencia en Atacama}

Estan constituidos por diversos actores, como líderes indígenas, arqueólogos, etnohistoriadores y antropólogos, quienes dan visibilidad y sentido a las cualidades culturales incomprensibles o simplemente irracionales antes personas externas a este grupo estudiado.

Los líderes Atacameños. Son un agente clave en la administración de la diferencia cultural. En Atacama se pueden identificar líderes indígenas de distintas jerarquías y competencias, como los líderes comunitarios, sociales, políticos yétnicos (las notas mostradas acá son recogidas de los cuadernos de campo propia 2010-2014).

$\mathrm{Al}$ respecto un Consejero Nacional Atacameño dice:

“Establezco una diferencia básica, los dirigentes de siempre son nativos de los pueblos, criados por sus abuelos en el campo, conocedores de los rituales y el conocimiento ancestral, que buscan mejorar condiciones y necesidades inmediatas y concretas".

Los Líderes Comunitarios son dirigentes de las localidades, elegidos democráticamente por miembros de la comunidad indígena. Una gran cantidad de ellos son mujeres, debido en parte a la particular dinámica de movilidad laboral masculina de la zona. Su competencia se asienta en las relaciones de parentesco y vecindad, con una fuerte identificación localista y solidaria. Estos líderes median conflictos internos propios de las familias. Son agentes de competencia local, buscan la obtención de recursos para la comunidad ante las agencias gubernamentales y privadas, también ante los líderes sociales y políticos atacameños. Más cercanos a las formas tradicionales de representación local, o al menos heredera de ellas, estos líderes surgen desde la base no tanto de sus capacidades, sino más bien por el cumplimiento de deberes con la comunidad, siendo una representación rotativa. Un dirigente de la comunidad de Talabre nos menciona que:

“después con la Ley Indígena se nos dijo que todos éramos atacameños, por eso hemos recibido más beneficios, se ha invertido en agua, luz y alcantarillado, en mejorar las semillas para las siembras y mejorar la crianza de los animales".

Este tipo de liderazgo tiene una vocación de reivindicaciones y demandas muy concretas, asociadas a las necesidades vitales de la población representada. 
Por otro lado, encontramos a los Líderes Sociales, básicamente los fundadores del movimiento atacameño con una vasta trayectoria de lucha por las demandas indígenas, que se han movido en períodos dictatoriales y democráticos. Estos movilizan instrumentalmente demandas sectoriales, básicamente socioeconómicas, ante las agencias de gobierno y privadas. Su competencia se asienta en las relaciones políticas y sociales intercomunitarias con una fuerte identificación corporativa de lo atacameño. La particularidad de este estrato dirigencial es el manejo y movilización de recursos y proyectos hacia las comunidades, hecho que les genera a los líderes sociales un beneficio de estatus y ciertos privilegios hacia ellos, sus familias y su comunidad. Una dirigenta social del Ayllu Conde Duque nos narra un episodio histórico:

“...- - recuerdo- lo primero que hace el gobierno militar es estimular la inscripción individual de este recurso, una de las primeras actividades como dirigente fue un catastro de las Mercedes de Agua inscritas. Hasta ese momento, toda nuestra gestión vecinal giró en torno a la no inscripción individual del recurso por una inscripción comunitaria. Esto fue un éxito, puesto que no se inscribieron individualmente, contrariando a las autoridades de la época y recién el año 96 se inscribe comunitariamente".

Claramente el agua es vista como un recurso económicosocial que une al pueblo Lican Antay, a través de una demanda muy sentida por la población transversalmente.

Un particular liderazgo lo sustentan los mediadores políticos atacameños. Son parte de la burocracia atacameña y su naturaleza es distinta a los anteriores, por lo general, son profesionales universitarios con cierta capacidad de negociación de demandas socioeconómicas. Estos líderes ajustan instrumentalmente las políticas gubernamentales o privadas con las demandas atacameñas, logran alinear estratégicamente esas demandas con los requerimientos de las agencias estatales (CONADI, INDAP, CONAF y SERNATUR) y empresas privadas (mineras y turismo). Bajo algunas circunstancias pueden ser verdaderos operadores o cultural bróker, estos suelen ser los que controlan las relaciones partidarias, de hecho son los operadores políticos comunales o regionales. A veces, no resulta claro si son agentes de partidos políticos o representantes de organizaciones indígenas. Por lo demás, el desempeño de su rol no carece de tensiones con el grupo de base que les da legitimidad y sustentación. Este liderazgo, en particular, está sometido a fuertes presiones desde la base y se sostiene en gran medida por el éxito en sus gestiones y la capacidad de redistribución de los beneficios. Por ello es parte de su estrategia "negociar dentro de lo posible", para obtener beneficios frente a los diversos agentes estatales y privados, con legislaciones desfavorables, en condiciones de abierta desigualdad?

En la actualidad, se da la emergencia de nuevas formas de poder concomitante y el surgimiento de prácticas contrahegemónicas, desde las propias organizaciones atacameñas y de una elite indígena como:

“Tanto fiel mensajero de su pueblo frente a los servicios públicos, tanto traductor de las directrices de estado frente a los miembros de su pueblo, ocupa una posición de cultural bróker" (Boccara y Bolados 2008: 184).

Este concepto nos permite identificar un actor estratégico en la etno-política atacameña y nos inserta en la complejidad del multiculturalismo, "derechos diferenciados en función de la pertenencia a un grupo" (Kymlicka 1996: 25).

Un último dirigente es el Étnico, defensor de los derechos de tercera generación y ambientalista, es parte de la performance nativista que captura un discurso civilizatorio bajo el prisma del primordialismo y esencialismo cultural. Es un líder moderno con redes sociales internacionales, defensor de los acuerdos y tratados internacionales.

7 Tanto los líderes sociales como los mediadores políticos, en la actualidad, son parte integrante de la burocracia atacameña fundamentalmente sanpedrina. La antigua militancia indígena unida a tecnócratas se moverá, desde fines de los noventa, al alero de la municipalidad de San Pedro de Atacama y de las agencias gubernamentales que financian programas sociales de desarrollo indígena en la zona. Estos mediadores políticos se encuentran determinados por su nueva posición dentro de la etnoburocracia, debiendo transmitir/traducir a los miembros de su pueblo las líneas de acción del Estado o de las empresas privadas. Su legitimidad dentro del campo burocrático intercultural depende en gran parte de su identidad, de indígena y de su doble capacidad por hacer entender "la razón de Estado" a sus coterráneos y transmitir a los funcionarios públicos las especificidades organizacionales y reivindicaciones sociales de los atacameños. 
Es un líder que defiende con vehemencia los derechos territoriales y lingüísticos en desmedro de demandas intermedias socioeconómicas, que según este tipo de liderazgo, sólo consolidan la desigualdad estructural en que vive el pueblo atacameño. Este tipo de líder está lejos de las agencias gubernamentales y privadas, son asesorados básicamente por abogados ${ }^{8}$ ambientales e indigenistas. El Presidente del Consejo de Pueblos Atacameños (2011) plantea que:

“...la sabiduría y equilibrio ancestral con los que sabemos reflexionar y actuar en las problemáticas y nuestro entorno, somos quienes más idóneamente pueden administrar y resguardar tanto los recursos naturales como los medioambientales".

Estas tipologías de líderes son dinámicas, en cuanto a la transitoriedad o temporalidad de cargos y funciones, existiendo algunos líderes sociales que han participado por largo tiempo como funcionarios o agentes gubernamentales. También es importante aclarar que los diferentes tipos de líderes se superponen, ya que un líder comunitario puede asumir como líder social en diferentes períodos o al mismo tiempo, dependiendo de las circunstancias, pueden asumir diferentes tipos de roles. Cabe mencionar que existen un conjunto de organizaciones productivas, deportivas y artísticas, entre otras, que aportan a través de sus expresiones visuales, sonoras y performática a la construcción de la atacameñeidad.

Los líderes atacameños son actores claves en el movimiento social indígena ciudadano atacameño, son quienes movilizan recursos y acciones colectivas con fines y propósitos para dar unidad a "lo Atacameño". Serán líderes de distintas jerarquías y competencias como los comunitarios, sociales, políticos y étnicos, los que encabezan los procesos de etno-patrimonialización que involucra tanto la construcción-revitalización de su identidad indiana (Rivera 1994; Gundermann 2003; Bolado y Boccara 2008; Morales 2014).

Ahora pasaremos a describir a otros administradores de la diferencia cultural, expertos o académicos con una fuerte tradición científica.

Los arqueólogos. La arqueología en Atacama recogerá la tradición de los naturalistas del siglo XIX, contratados por el Estado de Chile para delimitar una unidad administrativa funcional a los intereses de la incipiente nación chilena ${ }^{9}$. De esta manera, la reproducción de nominaciones no es casual, ellas responden a matrices clasificatorias-evolucionistas que dotan de un significado cultural a la palabra "atacameño". El objeto de estudio inicial de la arqueología en Atacama fueron los grupos étnicos, entendidos como vastos conglomerados, definidos básicamente por criterios lingüísticos, rasgos culturales materiales, tecnológicos, estilísticos e iconográficos. La elección del nominativo atacameño puede ser calificado como pro nacionalista ${ }^{10}$. El término es el menos indicado para denominar a los cunza o lickan antay, ya que existen distintos grupos que además trascienden las fronteras nacionales entre Argentina, Bolivia y Chile.

Para profundizar en ello, se destaca la discusión ocurrida en el primer Congreso Internacional de Arqueología en San Pedro de Atacama (1963), porque pone en el centro del debate la tesis de continuidad cultural, primordialista, de los atacameños desde tiempos prehispánicos hasta la actualidad, y la postura de abandonar las categorías étnicas por la designación de las culturas prehispánicas y sustituir la denominación más constructivista de Cultura Atacameña por la de Complejo Cultural San Pedro (Ayala 2006).

En la editorial del primer número de la Revista de Estudios Atacameños, Serracino 1973, nos dice:

8 Estos profesionales juegan un papel técnico muy importante en los procesos de judicialización de las demandas y reivindicaciones indígenas, convirtiéndose en litigantes especializados en el derecho internacional de protección de minorías étnicas a través del cumplimiento de las resoluciones del Comisión Interamericana de Derechos Humanos, Convenio 169 de la OIT. Estos abogados indigenistas junto a las organizaciones y líderes indígenas emprenden luchas judiciales sobre derechos colectivos e intelectuales de sus recursos y patrimonios naturales-culturales, ante las grandes empresas mineras y turísticas de la zona.

9 Expedición arqueológica de Senechal (1904), Schuller (1907) y Uhle (1903,1918).

10 El vocablo "atacameño", es una palabra quechua castellanizada con un gentilicio que alude a la nominación geográfica del lugar de estos pobladores. En la actualidad existe una comunidad atacameña boliviana de Quetena, cerca de seis comunidades aborígenes atacameñas en Argentina y 27 comunidades indígenas atacameñas en Chile. 
"Algunos autores cuestionan el uso de la palabra atacameña para los periodos prehistóricos anteriores a los escritos coloniales, con el argumento de que es imposible saber hasta qué punto, en tiempos pasados, esta gente fue la misma. Creo que también que hoy día son pocos los arqueólogos que niegan que los rasgos de la arqueología en San pedro de Atacama y sus alrededores son propios de esta zona, vale decir, que no se encuentran en otros lugares en las mismas dimensiones cuantitativas y cualitativas y en una forma continua a través del tiempo aun cuando el pueblo cambie sus costumbre e incorpore otras de las culturas vecinas. Por tanto es justo que se use la palabra atacameña para los periodos prehistóricos, si aún se duda de la validez de este argumento queda el hecho que los atacameños existieron y ocuparon un territorio determinado en tiempo históricos, por tanto, los yacimientos que se encuentran en el área ocupada por ellos son arqueología atacameña en el sentido en que se habla hoy de arqueología chilena" (Serracino 1973: 3).

La idea de continuidad cultural llevó a organizar un modelo de desarrollo o evolución cultural donde se enfatizó en la cultura material atacameña. A principios de los 9o, con ciertas modificaciones, las investigaciones arqueológicas retomaron categorías étnicas en los trabajos sobre prehistoria regional, postulando una continuidad cultural entre las sociedades prehispánicas tardías, los indígenas coloniales y contemporáneos (Uribe et al. 2003; Agüero et al. 2006).

La yuxtaposición del saber experto e indígena, más lo divulgado por el primer gobierno de la Concertación Democrática post dictadura, contribuyó al reconocimiento de la etnia atacameña para su inclusión en la Ley Indígena 19.253. Los líderes y organizaciones atacameñas presentaron publicaciones arqueológicas que avalaron su presencia en estos territorios desde tiempos prehispánicos. En este contexto, el discurso arqueológico ha contribuido a legitimar, desde la autoridad que impone la ciencia, los procesos de diferenciación de distintas colectividades indígenas del país. Al respecto, cabe mencionar que es recurrente la utilización de datos arqueológicos en las solicitudes de constitución de las comunidades atacameñas, tal como se puede apreciar en la documentación entregada a las agencias de gobierno (Ayala 2006).

Lo atacameño activa procesos que responden a una apa- rente unidad y es recogido, en la actualidad, por líderes y organizaciones indígenas para dar nombre a la etnia. La alcaldesa de San Pedro de Atacama nos menciona que:

“...nosotros no somos aymaras, por información de nuestros propios abuelos ${ }^{11}$ y también por estudios arqueológicos del Museo Gustavo Le Paige (...) no éramos ni aymaras ni quechuas y que nos reconocíamos como atacameños".

Este fragmento nos da cuenta de dos fuentes de autoridad e información para esta líder: tanto los estudios arqueológicos del Museo Gustavo Le Paige como sus propios abuelos como fuentes validadas, quienes dan los argumentos para diferenciarse de otros grupos vecinos como los aymaras y quechuas ante la Ley Indígena (1994).

Los etnohistoriadores. Los antecedentes etnohistóricos dan cuenta de una activa presencia de grupos culturales en distintos puntos colindantes a los denominados tempranamente "atacamas" (Bibar 1558; Oviedo 1557) por sus vecinos chichas, aymaras, omaguacas y calchaquíes cada uno con su propia lengua (Salas 1945; Lozano 1581; Serrano 1947).

Jerónimo de Bibar (1558) sobre Atacama dice:

"Las casa en que abitan los indios son de adobe y dobladas con sus entresuelos hechos de gruesa bigas de algarrobas, qu' es madera rrecia. Son todas/ estas casas lo alto d' ella de tierra de barro, a cavsa que no llueve. Encima d' esto terrodos, a manera de hornos en que tienen sus comidas (qu' es mays e papas y frijoles y quinua, algarroba y chañer, que tengo dicho, del qual tanbien hacen vn gustoso breuaje para beuer e miel)" (Saez-Godoy 1979: 20).

11 Los tata-abuelos, más conocidos como los "antiguos", señala un pastor "ellos son los constructores de estancias y Apachetas; los antepasados, deben ser tratados con mucho respeto", se tiene la creencia de que son proclives a enviar males, habitan las peñas en las quebradas, son los hacedores y constructores de todo lo que existe humanamente. Los lugares habitados por los antiguos son denominados como "gentiles o gentilares" y se asocian a los cerros tutelares, denominado malkus o maico (Morales 1997). 
Este fragmento nos muestra algunas características que hoy llamaríamos sociales. Las casas de adobe y gruesas vigas de algarrobo, diferentes a otras provincias habitadas por indios, además equipadas con hornos con comida (maíz, papas, frijoles y un brebaje de miel).

Respecto de Atacama, el profesor Martínez (1990b), constata para el siglo XVI la presencia temporal o estable de individuos de al menos 17 procedencias étnicas distintas en la región. La gran mayoría de estos datos, sin embargo, se refieren a casos aislados o que no permiten suponer una relación institucionalizada regionalmente. Para el siguiente siglo identifica:

"Uno de los aspectos más fundamentales de la complementariedad atacameña es la interetnicidad: las distintas estrategias orientadas a diversificar el control de recursos involucraban a variados grupos étnicos, contribuyendo así, de manera importante, a la formación de un espacio macro-regional común" (Martínez 199ob: 13).

Serán las actas judiciales, crónicas y registros coloniales los que entregarán una determinada fisonomía a la población de Atacama para el siglo XVI, XVII y XIX. Ello sin duda repercute en los imaginarios colectivos actuales, como verdaderos insumos para recrear estilos de vidas indígenas o mestizos (Martínez 1985; Hidalgo 2004; Sanhueza 2009).

Los antropólogos. Juegan un papel crucial en la construcción de una alteridad o una otredad como reflejo y contorno de los límites de sí mismo. Se genera así un "otro" traducible y por ende administrable. Sí bien antes se buscaba fijar identidades puras y separadas, hoy se sistematiza la fragmentación, las identidades fluidas y la hibridez colonizada, se trata de afirmar y ordenar la diferencia. En tal sentido, se reconocen las diferencias dentro de una economía general del poder: el triple imperativo de diferenciar, incorporar y administrar. Por un lado, indagar en la híper diversidad e investigar las operaciones que han hecho posible la etnización de grupos rurales, campesinos e indios. Por otro lado, traducir la diferencia y normalizar contenidos culturales para la integración de estos a las políticas públicas e intervenciones multiculturales (Grebe y Blas-Hidalgo 1988; Rivera 1994; Castro 1996; Gundermann 2002; Bolado y Boccara 2008; Morales 2014).
Sin duda los antropólogos, como expertos de la diferencia cultural y agentes de este campo étnico en Atacama, no han tenido una presencia tan sistemática en el siglo XX como la arqueología, sobre todo comparando con la repercusión de la presencia del Sacerdote Le Paige y el mismo Museo Arqueológico de San Pedro de Atacama. Pero su rol en la dinámica de las diferencias en Atacama en las últimas dos décadas ha sido significativo a través de los proyectos de investigación internacionales y nacionales, como el Fondo para el Desarrollo de la Ciencia y la Tecnología (FONDECYT), tambien se destacan las actividades de evaluación ambiental y diagnóstico cultural, demandados por agencias gubernamentales y privadas mineras. La antropología ha contribuido desde diversas perspectivas al entendimiento de un sujeto indígena fragmentado, complejo y heterogéneo.

Podemos afirmar que estos agentes de la diferenciación cultural están en un abierto proceso administrativo que lleva a la inclusión de grupos. De este modo las diferencias culturales son traducidas y puestas en codificaciones públicas para ser gestionadas. Luego serán incluidas a los circuitos de convivencia multicultural, ajustándose la normalización de la diferencia a los marcos sociales y jurídicos vigentes.

\section{Escenario de fricciones $y$ fisuras sociales en Atacama}

En el presente contexto multicultural en Atacama, emergen actores, instituciones y grupos con intereses que participan activamente en las políticas por el reconocimiento cultural. Trataremos dos casos para aplicar nuestro modelo de análisis.

La fricción ${ }^{12}$ por el agua en Pampa Colorada. Las fricciones culturales son situaciones conflictivas que emanan de la lucha por imponer distinciones específicas sobre los mar-

12 Frederick Barth $(1976,1995)$ llama fricción interétnica a una forma de describir la situación de contacto entre grupos étnicos irreversiblemente vinculados unos a otros, a través de los conflictos (manifiestos) o las tensiones (latentes) existentes entre ellos. Estos conceptos nos permiten abrir un espacio a la intensa lucha de los grupos étnicos en contacto, donde se construye un locus de control mutuo, así ambas partes mantendrán unas creencias y cambiarán otras. 
cadores culturales en juego (creencias, territorio, formas de organización, percepciones sobre el entorno, etc.). Las fricciones en Atacama nos permiten caracterizar los contornos culturales, tanto de los atacameños como de los grupos involucrados. Estas pueden ser pesquisadas en las disputas, por ejemplo, entre comunidades indígenas y empresas mineras. Ambas compiten por el "agua", recurso esencial tanto para la actividad industrial minera como para las actividades pastoriles y agrícolas de las comunidades (Bolados 2014; Azocar 2014).

En el Segundo Congreso Atacameño 2008, los comuneros mencionaron que la principal causa de los problemas asociados al cultivo y la ganadería están en la falta y calidad del agua. La escasez de agua tiene dos tipos de explicaciones, una material y otra simbólica:

"la primera, tiene que ver con la acción de las empresas mineras y otros organismos que tienen y hace uso exclusivo del agua; la segunda, alude a la pérdida de costumbres, en particular, de los ritos de religiosidad andina para efectuar ofrendas y pagos a la Pacha-Mama, esto último afectaría principalmente en la disminución de las lluvias y con ello el pasto en los campos para alimentar al ganado" (Segundo Congreso Atacameño 2008: 27).

La pérdida parcial de la ritualidad atacameña y la acción de las empresas mineras sobre el agua, son una fuente explicativa del secamiento de vegas y la correspondiente disminución de recursos forrajeros para las actividades pastoriles. La solución a los problemas tanto agrícolas como ganaderos se asocia a una mayor cantidad de agua disponible y a retomar prácticas rituales-religiosas que restablecen equilibrios entre la naturaleza y la actividad humana según sus propios dirigentes. El proyecto "Suministro de Agua Pampa Colorada" entre otros, buscó la extracción de aguas subterráneas desde acuíferos en una cuenca altoandina, para abastecer los procesos productivos de la empresa Minera Escondida ${ }^{13}$. El vicepresidente de asuntos corporativos de esta minera dice:

"entiendo que en el desierto el agua es un bien escaso". Pero agrega que "los derechos de agua que la empresa quiere utilizar no son aguas actualmente consumidas por las comunidades o de las cuales estén haciendo uso. No hay una competencia por los derechos de agua. No tiene que ver una cosa con la otra" (Jaque 2007: 35).
Las comunidades indígenas de Peine, Socaire, Taladre, Cama y Toconao reclaman a fin de que la juridiccion estatal les reconozca el dominio de esas tierras, en virtud de los artículos $n^{\circ} 12, n^{\circ} 63$ y $n^{\circ} 3$ transitorio de la Ley Indígena. Sandra Berna, alcaldesa, integrante de la etnia atacameña, dice:

"cuesta tener agua en la región, mantener los bofedales es mantener el culto que le rinden al recurso las comunidades atacameñas. Para nosotros el agua no tiene precio, es de las comunidades de San Pedro y no hay ningún negocio que hacer, sólo cuidarla. Se quieren llevar un gran tesoro". Berna asegura que las comunidades y su municipio están en la misma cruzada. "No necesitamos plata, sino saber que vamos a vivir muchas años más en nuestra tierra" (Jaque 2007:35).

La fricción se genera porque para la empresa minera, el "agua" tiene sólo un valor económico, en cambio para las comunidades y líderes indígenas, este valor, es también simbólico/esencial/sustantivo. Se está frente a una disputa, con cierta eficiencia discursiva para las organizaciones indígenas, donde las diferencias culturales se evidencian en las distintas concepciones respecto de un mismo recurso, sistematizado por antropólogos e etnohistoriadores.

La politización del movimiento indígena atacameño representada en su Segundo y Tercer Congreso (2008, 2009), logra transformar la fricción "agua" en "territorio". Así como antes fue el "agua”, ahora será la idea de "territorios ancestrales", conceptos que serán asociados a un discurso indiano de "armonía andina", "prístino", "hermandad". Ello será la base para un discurso de lucha civilizatoria:

“...somos dueños ancestrales de este territorio por el hecho que hemos estado en estas tierras desde tiempos inmemoriales. Usando y cuidando sus elementos natu-

13 Este proyecto tiene capacidad para suministrar un total de 648 millones de metros cúbicos de agua, a una tasa de extracción media anual máxima de 32,4 millones de metros cúbicos. Lo que equivale a un caudal de extracción medio anual máximo de 1.027 litros por segundo. El proyecto implica una inversión aproximada de 300 millones de dólares y considera una vida útil estimada inicialmente en 20 años. 
rales en una relación de armonía y hermandad propia de nuestra cosmovisión andina......la propiedad ancestral sobre las aguas que se ubican en nuestro territorio ya que estas son indispensables para asegurar la vida cultural y material atacameña" (Segundo Congreso Atacameño 2008: 32-33).

La idea de ancestralidad arqueológica remite a tiempos inmemoriales, y permite construir la dicotomía valor económico/ritual. De esta manera se enarbolan grandes divisiones: naturaleza, limpia, prístina, primordial, esencial, sustancial, nativa e india, versus ciudad contaminada, maldad, artificialidad y violencia, todo reforzado con un conjunto de artillería conceptual ambientalista e indianista. De aquí se desprenden estrategias a seguir, y tomará un lugar central la defensa de los derechos colectivos. De esta manera, se demandará: restitución de aguas, prohibición de exploración de agua y declarar el Salar de Atacama como cuenca saturada. Cada una de estas reivindicaciones surgen del campo de la negociación y se convierten en verdaderos emblemas de etnicidad, no negociables y constitutivos de un orden atacameño primordial.

Fisuras ${ }^{14}$, pactos de integración y racismo. Atribuimos la condición de fisura a las consecuencias del pacto social entre la sociedad atacameña de fines del siglo XIX y el Estado de Chile, triunfante de la Guerra del Pacífico (1879-1883). Este pacto implica la chilenización de la zona de Atacama, que consistió en un conjunto de operaciones clasificatorias destinadas a jerarquizar personas según sus cualidades físicas y sociales, lo que permitió la incorporación y exclusión de poblaciones de Atacama a la nueva jurisdic-

14 Por otro lado, la idea de "fisuras generativas" de Valenzuela (1999), diferencia las rupturas sociales e históricas de amplio alcance, de aquellas fricciones propias del contacto cultural. Se empleó aquí esta noción como un punto de apoyo para describir las relaciones étnicas en Atacama, a través de procesos históricos locales como la chilenización. Las fisuras generativas serían aquellas divisiones sociales perdurables, que tienen un papel importante en la estructuración de los espacios sociales locales y que la tienen, en la medida que dan origen a agentes sociales y a una acción social concomitante con ellas. Lo interesante de las fisuras es que producen alineamientos de sujetos, definiciones de propósitos, especificaciones de identidad e identificación. ción nacional chilena. La fórmula que permite este doble propósito es la distinción chileno/boliviano, atacameño/ colla y atacameño/quechua. Este alineamiento estratégico de sujetos permitió ubicar a los atacameños como propietarios agrícolas integrados a una vida nacional en San Pedro de Atacama, y al mismo tiempo negar la integración de collas y quechuas al ser considerados extranjeros. Pese a la no integración formal de collas y quechuas, estos grupos fueron y son parte fundamental del orden atacameño. Orden que se levanta sobre una estructura social clasista y racista (Barros 2008), que jerarquiza en base a comportamientos o hábitos (lingüísticos reproductivos, alimenticios o vestimenta, entre otros) y por supuesto también por el color de piel.

La sociedad atacameña, lejos de ser un grupo homogéneo, está cruzada por fuertes divisiones sociales dentro de una disposición jerárquica que permite la visibilidad de grupos integrados y otros menos proclives a la integración. Estos últimos descalificados, según los testimonios recopilados, por sus conductas refractarias al orden moral y jurídico nacional chileno. Nos referimos a los grupos denominados collas de la puna de Atacama y a los quechuas de la cuenca El Loa, todos reunidos bajo la categoría de "boliviano" o "extranjero". Cabe mencionar que dicha descalificación no sólo responde a agrupaciones sociales específicas, sino también a comportamientos individuales y sociales asociados a borracheras, mal hablar del castellano, higiene personal, vestimenta y alimentación, entre muchos más (Morales 2013, 2014).

A partir de lo expuesto proponemos una etnogénesis atacameña como paradójica, pues tiene una doble factura: es molde de integración y exclusión, lo que solo es posible en un lugar donde conviven varios grupos culturales. Además no es posible abstraerse a la mercantilización de la vida cotidiana a raíz del impacto del turismo y la minería en la zona. Los procesos de visibilización de sujetos sociales no solo responden a los intereses y agencias de los grupos comprometidos, sino también a las posibilidades que entrega el mercado, como consumidores o productores de bienes y servicios. Los grupos de Atacama no están ajenos a esto, en una zona de gran importancia económica por la minería extractiva, el turismo y el intercambio comercial transfronterizo.

“...la etnogénesis se traduce por el surgimiento de una 
nueva entidad sociocultural cuya estructura social e identidad poco tienen que ver con las de los grupos de su origen. Se podría decir que la historia que vamos a contar y que hemos intentado reconstruir es la historia de una metamorfosis" (Boccara 1999: 20).

Esta génesis atacameña de fines del siglo XIX y principios del XX es la emergencia de un "sujeto social", un campesino agricultor, propietario y mercantilizado producto de la fuerte actividad ganadera de traslado de animales de Argentina a las oficinas salitreras de la costa. Paradójicamente, la incorporación al imaginario nacional estuvo supeditada a la fijación de la cultura atacameña, en tanto parte de un pasado integrante de la memoria nacional, pero inexistente en el presente.

Serán los estudios de la arqueología atacameña los que reafirmaron la densidad étnica para convertirse en un referente de alteridad en Chile. Al mismo tiempo, lo que está fuera de lo atacameño claramente se identificó como lo extranjero, todas las prácticas culturales que escapan a los parámetros de la homogeneidad nacional. Se consolida así la idea de un alter colla, quechua o simplemente boliviano, cargado con características negativas: borracho, sucio, lengua extraña y criador de llamo, finalmente el indio. Por otro lado, aparece un Ego-atacameño campesino mestizo con hábitos criollos; su referencia cultural será la sociedad chilena de fines del siglo XIX, con cualidades de limpio, responsable, castellanizado y de hábitos modernos. Sin duda que los complejos sistemas clasificatorios ideados por los atacameños apuntan a ordenar desde su propia óptica de dominación a los diversos grupos en Atacama. Las diferencias adquieren alcances sociales, simbólicos e incluso raciales a propósito de la construcción de estereotipos sociales y la creación de oposiciones a partir de los estilos de vida diferentes, que terminarán irremediablemente con los clasificadores, los atacameños de San Pedro de Atacama, en la cúspide de la estratificación social (Morales 2013).

Esta fisura nos muestra la etnicidad atacameña como una relación social histórica, muchas veces inestable, temporal, contextual y dinámica, que se construyó y se construye en la interacción, con otros grupos sociales, sean estos vecinos, nacionales o empresas.

En la actualidad el movimiento indígena atacameño es heredero de las actuales fricciones interétnicas que politiza las demandas territoriales, y de las viejas fisuras que adquieren relevancia en las clasificaciones racistas.

\section{Etno-política atacameña}

Por lo expuesto hasta aquí, podemos afirmar la existencia de un campo étnico, donde se define "un sujeto para la política étnica" y "un sujeto étnico para la política”. La problematización de lo étnico a través de la etnificación, como un proceso administrativo de los asuntos de la diversidad cultural y estructura que organiza las luchas, conflictos, resistencias y asimilaciones. Lo que justifica la construcción de este campo, es la necesidad de evitar conflictos bélicos, debido a los costos que ello implica. Así, el reconocimiento y la participación depende y dependerá de las condiciones históricas, sociales, económicas y políticas involucradas (Zambrano 2002). De acuerdo con los presupuestos teóricos del campo propuesto, éste es un sistema de relaciones sociales, definido por la posesión y producción de una forma específica de capital. Cada campo, en nuestro caso atacameño, es en mayor o menor medida autónomo; la posición dominante o dominada de los participantes en el interior del campo depende en algún grado de las reglas específicas del mismo. El conjunto estructurado del campo incluye sus influencias recíprocas y las relaciones de dominación entre ellos, esto define la estructura social ${ }^{15}$.

Este sujeto social atacameño, lejos de ser un proyecto estatal contemporáneo, tiene su propia génesis. Como lo hemos visto, son varios acontecimientos que fundaron y fundamentan un proceso de formación de un sujeto social y su etnogénesis paradójica a fines del siglo XIX y principios del XX, proclive a la chilenización de Atacama (Morales 2013). Por otro lado, el reconocimiento legal de la etnia atacameña en 1994 es el simple reconocimiento de un sujeto estable, con cualidades claramente definibles y abordables por las políticas públicas y privadas. La inclusión de los atacameños se debe a su condición histórica de integración nacional y a su posición hege-

15 Para entender mejor la idea de "campo" de Bourdieu (1990) es necesario revisar el concepto de habitus como un conjunto de disposiciones adquiridas, un sistema que funciona a modo de principios clasificatorios que organizan la acción colectiva. 
mónica sobre grupos vecinos, gestada por las propias etno-burocracias al alero del municipio atacameño, que además se compone mayoritariamente por líderes de San Pedro de Atacama. Como se mencionó, se consolida un sujeto social para las políticas de Gobierno que realizan sus intervenciones en materia como Áreas Protegidas, patrimonio, género e igualdad, emprendimientos comerciales, desarrollo productivo o fomento de las artes, entre otros. También se consolida un sujeto étnico-actor individual, un líder o mediador performático de la política de las diferencias culturales.

En este contexto de agentes y agencias, se identifica un especie de capital étnico atacameño como un activo económico, incluso podemos catalogar como un capital de riesgo, justamente el riego, lo constituye la diferencia cultural como inefable, intraducible o incomprensible. Resulta extravagante que líderes indígenas y expertos sean los mediadores de las certezas e incertidumbres de estos capitales.

La idea de capital ${ }^{16}$ nos lleva al debate actual sobre la identidad o cultura como mercancía o parte de ella, y también a la noción de propiedad intelectual o copyright. Estos elementos se articulan con la idea de empresa, son propios de una economía de consumo en la cual la identidad social aparece mediada por procesos de mercantilización. Sin dudas, esto excede en mucho a la cuestión étnica y tiene que ver con las características que toman las identidades en los contextos neoliberales:

"la apoteosis de la propiedad intelectual y la reducción de la cultura a propiedad intelectual (...), el desplazamiento de la política hacia el ámbito de lo jurídico, y la creciente naturalización del tropo de la identidad, en especial de la identidad cultural, que aparece como esencia, y, a la vez, como objeto de elección, construcción y consumo" (Comaroff y Comaroff 2011: 230-231).

Las empresas indígenas en Atacama se han formalizado

16 La distinción clásica de Bourdieu entre capital cultural y económico se vuelve difusa, pues al ser cultural es intrínsecamente pública, orgánica y no tiene límites, y por consiguiente no es posible reducirla a un sistema de propiedad privada (individual o colectivo o la propiedad Intelectual como un valor eurocéntrico). como administradoras de Áreas Protegidas y de turismo comunitario. Han certificado productos de origen y patrimonio genético de flora y fauna endémica en la Puna de Atacama, han inscrito aguas superficiales y autorizado el uso de imágenes y lugares para publicidad comercial. Así, la propiedad intelectual y la noción de territorio han hecho surgir la preocupación por preservar el patrimonio cultural y natural del pueblo atacameño. Las organizaciones y líderes han recorrido un largo camino en estas últimas décadas buscando el reconocimiento de sus derechos económicos, culturales y ambientales.

\section{* Comentarios finales}

Las diversas perspectivas y enfoques de lo étnico nos muestran que las definiciones no son neutrales o inocuas, por el contrario, según el agrupamiento del conjunto de fenómenos diferenciadores, generan realidades y operaciones epistemológicas que explican y sustentan la diferenciación humana.

Los rasgos que son tomados en cuenta por las organizaciones, líderes y expertos atacameños a modo de marcadores centrales de diferenciación, no se corresponden con la suma de las diferencias objetivas, sino particularmente con aquellos que los actores mismos consideran significativos.

La hegemonía política del grupo atacameño de San Pedro de Atacama sobre sus vecinos de la Puna, a quienes denomina como collas, quechuas, bolivianos o runacos, nos muestra fisuras generativas o divisiones sociales perdurables que tienen un papel importante en la estructuración de los espacios sociales locales, en la medida que dan origen a sujetos sociales y a una acción social coherente con ellos.

Por otro lado, las fricciones culturales se expresan de forma permanentes entre las poblaciones indígenas y no indígenas. Esto nos muestra que la etnopolítica atacameña opera sobre algunos rasgos culturales que son utilizados por los actores como emblemas de diferencia o marcadores culturales.

Esta política de la diferencia cultural ha sido llevada a cabo por una burocracia indígena atacameña, compuesta por líderes y tecnócratas, también por académicos y ex- 
pertos que conducen la política local desde los procesos vecinales y electorales hasta las reivindicaciones lingüísticas o de autodeterminación. La emergencia de un movimiento social ciudadano atacameño marca un hecho trascendental en Atacama. Es la decisión orgánica de caminar juntos, no sin problemas y divisiones, en pos de la conquista de derechos como minoría étnica.

Finalmente, se caracterizaron las nuevas formas de acción política de las dirigencias indígenas y expertos que son parte sustancial del procesos diferenciales, administrativos e inclusivos en un Campo Etnopolítico atacameño. Se da cuenta que una cuestión; que fue el reconocimiento e integración de grupos indígenas atacameños producto de la Ley Indígena (1994), y otra muy diferente, tratado aquí, el entablado de las interacciones entre los líderes indígenas, expertos, movimientos sociales ciudadanos, empresas y la institucionalidad que hacen posible la realización de la diversidad cultural en la política.

\section{Agradecimientos}

A colegas y evaluadores por sus comentarios y sugerencias en miras del perfeccionamiento de este escrito. Asimismo, agradecemos a las autoridades y comuneros atacameños por sus valiosos aportes.

\section{* Referencias Citadas}

AGÜERO, C., AYALA, P., URIBE, M., CARRASCO, C. Y CASES, B. 2006. El Período Formativo desde Quillagua, Loa Inferior (norte de Chile). Esferas de interacción prehistóricas y fronteras nacionales modernas: Los Andes Sur Centrales. H. Lechtman, Lima, Perú.

ANDERSON, B. 1993. Comunidades Imaginadas: reflexiones sobre el origen y la difusión del nacionalismo. Fondo de Cultura Económica, México.

AYALA, P. 2006. Relaciones y discursos entre atacameños, arqueólogos y Estado en Atacama (II Región, norte de Chile). Tesis para optar al Grado de Magíster en Antropología, Universidad Católica del Norte y la Universidad de Tarapacá, San Pedro de Atacama, Chile.

AZOCAR, R. 2014. Pampa Colorada: conflicto etno-ambiental y Movimiento Indígena Atacameño. Memoria para optar al Título de Antropólogo Social. Universidad de Chile, Chile.

BARROS, A. 2008. Identidades y propiedad: Transiciones territoriales en el siglo XIX atacameño. Estudios Atacameños Arqueologíay Antropología Surandinas 35: 119-139.

BARTH, F. 1976. [1970]. Los grupos étnicos y sus fronteras. Fondo de Cultura Económica, México.

BARTH, F. 1995. "Ethnicity and the concept of culture". Paper presentado en Conference rethinking culture. Disponible en http:// www.tau.ac.il/tarbut/readers/syllab/fbarth-ethniciy.htm.

BARTOLOMÉ, M. 2004. Procesos interculturales: antropología política del pluralismo cultural en América Latina. Editorial Siglo XXI, México.
BELLO, A. 2004. Etnicidad y ciudadanía en América Latina. La acción colectiva de los pueblos indigenas. Libros CEPAL-GTZ, Santiago, Chile.

BERGER, P. y T. LUCKMAN. 1973. La construcción social de la realidad. Amorrortu Editores, Buenos Aires, Argentina.

BIBAR, J. 1966. [1558]. Crónica y relación copiosa y verdadera de los reinos de Chile. Fondo Histórico y Bibliográfico José Toribio Medina, Santiago, Chile.

BOCCARA, G. 1999. Etnogénesis mapuche: resistencia y reestructuración entre los indígenas del centro-sur de Chile (siglos XVIXVIII). Hispanic American Historical Review. 79: 425-461.

BOCCARA, G. 2002. Construyendo identidades desde el poder: los indios en los discursos republicanos de inicios del siglo XIX. En Mestizaje, Identidades y Poder en las Américas. G Boccara (Ed), pp 27-46.

Abya-Yala-IFEA, Quito, Ecuador.

BOCCARA, G. Y P. BOLADOS, 2008. Dominar a través de la participación. Memoria Americana 16: 167-196.

BOLADOS, P. 2014. Los conflictos etnoambientales de "Pampa Colorada" y "El Tatio" en el salar de Atacama, norte de Chile. Procesos étnicos en un contexto minero y turístico transnacional. Estudios Atacameños Arqueología y Antropología Surandinas 48: 229-248.

BOURDIEU, P. 1990. Sociología y cultura. Editorial GrijalboCONACULTA, México. 
CASTRO, M. 1996. Llameros de puna salada en los Andes del norte de Chile. En Pastoreo altoandino. Realidad, sacralidad y posibilidades, J. Flores Ochoa y Y. Kobayashi (eds.), pp, 85-109. Editorial Plural-Museo Nacional de Etnografía y Folklore, La Paz.

CASTRO, M. Y BAHAMONDES, M. 1998. Ia ckari latckiturnisaya sema Lickana, el amanecer de un nuevo pueblo. Actas del Primer Congreso Nacional Atacameño. CONADI/CIDER Consultores, Santiago, Chile.

COHEN, A. 1974. Introduction: The Lesson of Ethnicity. En Urban Ethnicity, ASAl. Tavistock Pub, Londres, Inglaterra.

COMAROFF, J. L. Y COMAROFF, J. 2011. Etnicidad S.A. Katz Editores, Buenos Aires, Argentina.

COMAROFF, J. L. Y COMAROFF, J. 2013. Teoría desde el sur o cómo los países centrales evolucionan hacia áfrica. Editores XIX, Buenos Aires, Argentina.

CONNOR, W. 1994. Ethno-nationalism. The Quest for Understanding. Princeton University Press, Nueva Jersey, Estados Unidos.

DEGREGORI, C. y PORTOCARRERO, G. 2004. Cultura y Globalización. Red para el desarrollo de las ciencias sociales en el Perú, Lima, Perú.

JAQUE, M. (2007). La guerra por el agua: El proyecto de extracción de minera Escondida y los riesgos para los atacameños, La Nación, 23/04/07.

DÍAZ POLANCO, H. 2006. Elogio de la diversidad: Globalización, multiculturalismo y etnofagia. Siglo XXI, México.

FOERSTER, R. 1999. ¿Movimiento étnico o etnonacional mapuche?. En Revista de Crítica Cultural 18: 52-58. Santiago, Chile.

ESCOLAR, D. 2007. Dones étnicos de la Nación. Identidades huarpe y modos de producción de soberanía en Argentina. Editorial Prometeo, Buenos Aires, Argentina.

GEERTZ, C. 1963. Old Societies and New Status. Free Press, Nueva York, Estados Unidos.

GEERTZ, C. 1993. Primordial loyalties and standing entities. En Public Lectures 7: 1-17. Collegium Budapest e Institute for Advanced Study, Budapest, Hungría.

GEERTZ, C. 1997. [1973]. La Interpretación de las Culturas. Editorial Gedisa, Barcelona, España.

GELLNER, E. 1988. Naciones y nacionalismo. Editorial Alianza, México.
GIMÉNEZ, G. 2006. El debate contemporáneo en torno al concepto de etnicidad. Revista electrónica de ciencias sociales 1: $129-144$.

GIMÉNEZ, G. 2000 . Identidades étnicas: estado de la cuestión. En Los retos de la etnicidad, L. Reina Coord, (Eds.) pp. 45-70. CiesasINI-Porrúa, México.

GLAZER, N. Y MOYNIHAN, D. 1975. Ethnicity: Theory and Experience. Harvard University Press, Cambridge, Estados Unidos.

GREBE, M. y HIDALGO, B. 1988. Simbolismo atacameño: un aporte etnológico a la comprensión de significados culturales. Revista Chilena de Antropología 7: 75-97

GOVERS, C. Y VERNEULEN, H. 1994. The anthropology of Ethnicity: beyond "Ethnic Groups and Boundaries". Het Spinhuis Publishers, Amsterdam, Holanda.

GUNDERMANN, H. 2002. Los Atacameños del S. XIX y S. XX, una Antropología Histórica Regional. Documento de Trabajo CVHNT/GTPIN/2002/051. San Pedro de Atacama.

GUNDERMANN, H. 2003. Sociedades indígenas, municipio y etnicidad: La transformación de los espacios políticos locales andinos en Chile. Estudios Atacameños 25: 55-77.

HIDALGO, J. 2004. Historia Andina en Chile. Editorial Universitaria, Santiago, Chile.

HOBSBAWM, E. 2002. [1983]. La Invención de la Tradición, pp. 7-21. Editorial Crítica, Barcelona, España.

HOPENHAYN, M. 2005. América Latina, desigual y descentrada. Grupo Editorial Norma, Argentina.

ISAACS, H. 1975. Idols of the Tribe, Group Identity and Political. Change. Harper \& Row Publishers, Nueva York, Estados Unidos.

KYMLICKA, W. 1996. Ciudadanía multicultural. Una teoría liberal de los derechos de las minorías. Editorial Ariel, Barcelona, España.

LOZANO, J. 1885. [1581]. Carta del Factor de Potosí al virrey del Perú, en donde se describe la Provincia de los lipes. Relaciones Geográficas de Indias, Perú, T. II, Apéndice III. Ministerio de Fomento, Madrid, España.

MARTÍNEZ, J. L. 199ob. Asentamientos y acceso a recursos en Atacama (s. XVII). En Economía y comercio en América Hispana, G. Bravo (Ed.), pp. 13-61. Serie Nuevo Mundo: cinco siglos, $\mathrm{n}^{\circ}$ 5. Departamento de Ciencias Históricas, Fac. de Filosofía y Humanidades, Santiago, Chile. 
MARTíNEZ, J. L. 1985. Adaptación y cambio en los atacameños. Los inicios del período colonial, siglos XVI y XVII. Revista Andes 3: 19-34.

MORALES, H. 1997. Pastores trashumantes al fin del mundo. Un enfoque cultural de la tecnología: en una comunidad andina de pastores. Memoria para optar al Título. Universidad de Chile, Santiago, Chile.

MORALES, H. 2013. Construcción social de la etnicidad. Ego y alter en Atacama. Estudios Atacameños 46: 145-164.

MORALES, H. 2014. Génesis, formación y desarrollo del movimiento atacameño (norte de Chile). Estudios Atacameños 48: 111-128.

MURDOCK, G. 1957. World ethnographic sample. American Anthropologist 59: 53-70.

NAROLL, R. 1964. On ethnic unit classification. Current Anthropology 5: 283-291.

OVIEDO, F. 1902. [1557]. Historia General y Natural de las indias, Islasy Tierra Firme del Mar Océano. Colección de Historiadores de Chile, Santiago, Chile.

PALMA, S. Y PARRA, E. 2008. Laycku ckotch heuur nisayá lickanantay, la autodeterminación del pueblo atacameño. Actas Segundo Congreso Atacameño, Toconao, Chile.

RIESMAN, D. 1953. The Lonely Crowd. Yale University Press, New Haven, Estados Unidos.

RIVERA, F. 1994 b. Identidad en el laberinto: La búsqueda del sentido étnico en San Pedro de Atacama. Estudios Atacameños 13: 61-73.

ROOSENS, E. 1989. Creating Ethnicity. The Process of Ethnogenesis. Sage Pub. Inc, California, Estados Unidos.

SAEZ GODOY, L. 1979. [1558]. Gerónimo de Vivar: Crónica y Relación Copiosa y Verdadera de la Conquista de Chile. Colloquium Verlag, Berlín, República Federal Alemana.

SALAS, A. 1945. El Antigal de Ciénega Grande. (Quebrada de Purmamarca, Provincia de Jujuy). Universidad de Buenos Aires, Buenos Aires, Argentina.

SANHUEZA, C. y GUNDERMANN, H. 2009. Capitales, Estado rentista y cambio social atacameño en las regiones interiores de Antofagasta (1879 - 1928). Revista Universum 24: 218-246.

SCHULLER, R. 1908. Estudios de la lengua de los indios. Lickan-Antay (atacameños)-Calchaqui. Imprenta Cervantes, Santiago, Chile.

SHILS, W. 1957. Primordial, personal, sacred and civil ties. British Journal of of Sociology 8: 130-147.
SERRACINO, G. 1973. Presentación. Estudios Atacameños 1: 2.

SERRANO, A. 1947. Los Aborígenes Argentinos.. Editorial Nova, Buenos Aires, Argentina.

SOLLORS, W. 1991. The Invention of Ethnicity. Oxford University Press, Nueva York, Estados Unidos.

STAVENHAGEN, R. 2001. La cuestión étnica. El Colegio de México, México.

STAVENHAGEN, R. 1992. La cuestión étnica: algunos problemas teórico metodológicos. Estudios Sociológicos vol. X (28): 23-34.

STAVENHAGEN, R. 2000. Conflicto Étnico y Estado nacional. Editorial Siglo XXI, México.

TAYLOR, C. 2003. Multiculturalismo y la politica de reconocimiento. Fondo de Cultura Económica, Madrid, España.

UHLE, M. 1903. Los indios atacameños. Biblioteca Iberoamericana 1912. Referencia N-0035 W 107. Berlín, Alemania.

UHLE, M. 1918. Los Aborígenes de Arica y el Hombre Americano. Imprenta de la Aurora, Arica, Chile.

URIBE, M. y ADAN, L. 2003. Arqueología, poblaciones originarias y patrimonio cultural en el Desierto de Atacama. Chungara, Revista de Antropología Chilena 35 (2): 295-304.

VALENZUELA, J. S. 1999. Reflexiones sobre el presente y futuro del paisaje político chileno a la luz de su pasado. Estudios Públicos 75:273-290.

VERGARA, J.I., GUNDERMANN, H. y FOERSTER, R. 2013. Estado, Conflicto Étnico y Cultura. Estudios sobre Pueblos Indígenas en Chile. Serie Qillqa, UCN-UA, San Pedro de Atacama, Chile.

VERMeUlen, H. y GOVERS, C. 1997. From Political Mobilization to the Politics of Consciouness. En The Politics of Ethnic Consciouness, C. Goverse y H. Vermeulen (Eds.) Macmillan Press, Reino Unido.

WARNER, W. y STROLE, L. 1945. The Social Systems of American Ethnic Groups. Yale University Press, New Haven, Estados Unidos.

WEBER, M. 1944. Economía y Sociedad, Vol. I. Fondo de Cultura Económica, México.

ZAMBRANO, W. 2002. Etnopolítica y racismo. Universidad Nacional de Colombia, Colombia.

ZIZEK, S. 1998. Multiculturalismo o la lógica cultural del capitalismo multinacional. Ediciones Paidós, Buenos Aires, Argentina. 